\title{
Kebutuhan Energi Untuk Pengolahan Bauksit di Kalimantan Barat
}

\author{
Edwaren Liun ${ }^{\star 1}$, Nurlalila ${ }^{1}$ \\ ${ }^{1}$ Pusat Kajian Sistem Energi Nuklir (PKSEN), Badan Tenaga Nuklir Nasional, Kuningan Barat, Mampang Prapatan, Jakarta- \\ Indonesia
}

\begin{tabular}{l}
\hline INFORMASI ARTIKEL \\
\hline Riwayat Artikel: \\
Diterima: \\
29 September 2020 \\
Diterima dalam bentuk revisi: \\
05 Februari 2021 \\
Disetujui: \\
07 Juni 2021 \\
\\
\hline
\end{tabular}

\section{Kata kunci:}

bauksit

alumina

aluminium

energi

listrik

batubara

PLTN

\begin{abstract}
ABSTRAK
KEBUTUHAN ENERGI UNTUK PENGOLAHAN BAUKSIT DI KALIMANTAN BARAT. Mineral bauksit yang terkandung di tanah Kalimantan Barat mempunyai potesi ekonomi jika diolah menjadi bahan baku (alumina) atau menjadi aluminium sehingga mempunyai nilai tambah yang tinggi. Pengolahan bauksit hingga grade aluminium meliputi tahap transformasi kimia antara lain pencucian, peleburan dan elektrolisis. Untuk pengolahan bauksit dilakukan dengan membangun smelter untuk mengolah bijih (bauksit) hingga menjadi bahan baku industri aluminium berupa alumina. Makalah ini bertujuan untuk menganalisis kebutuhan energi berupa panas dan listrik pada pabrik alumina. Metodologi yang digunakan dalam penelitian adalah penelusuran pustaka dan analisis benchmarking dengan melakukan perhitungan pada setiap langkah proses yang melibatkan data dan formula terkait. Perhitungan mencakup kuantitas energi panas, energi listrik dan aspek yang terkait dengan sumber energi yang dibutuhkan seperti batubara, energi nuklir dan energi lainnya bagi pembangkit listrik di masa mendatang untuk mendukung industri ini. Dari hasil analisis diperoleh bahwa kebutuhan energi setara untuk grade alumina adalah pada kisar 611 ribu ton batubara untuk menghasilkan satu juta ton alumina. Pengolahan dari alumina menjadi satu juta ton aluminium per tahun membutuhkan ketersediaan pembangkit listrik sebesar 2 ribu MW. Besarnya kebutuhan energi listrik untuk mencapai grade aluminium membutuhkan pembangkit berskala besar yang kemungkinannya akan terpenuhi oleh PLTN berskala besar karena wilayah ini mengandung kekayaan uranium sedangkan batubara dan sumber energi fosil lainnya tidak tersedia secara memadai.
\end{abstract}

\begin{abstract}
ENERGY REQUIREMENT FOR THE PROCESSING OF BAUXITE IN WEST KALIMANTAN The bauxite mineral contained in the soil of West Kalimantan has economic potential if it is processed into raw material (alumina) or into aluminum so that it has high added value. The process of bauxite to grade aluminum includes chemical transformation stages including washing, smelting and electrolysis. The processing of bauxite is performed by building a smelter to process ore (bauxite) to become the raw material for the aluminum industry in the form of alumina. The aims of this paper is to analyze the energy demand in the form of heat and electricity at an alumina plant. The methodology used in this research is literature studies and benchmarking analysis by performing calculations at each step of the process involving related data and formulas. The calculation includes the quantity of heat energy, electrical energy and aspects related to the energy sources needed such as coal, nuclear energy and other energy for future electricity generation to support this industry. From the analysis, it was found that the equivalent energy demand for alumina grade is in the range of 611 thousand tons of coal to produce one million tons of alumina. Processing of alumina into one million tons of aluminum per year requires the availability of a power plant of 2 thousand MW. The amount of electrical energy demand to reach aluminum grade requires large-scale of power plants which are likely to be met by large-scale nuclear power plants because this area contains uranium wealth while coal and other fossil energy sources are not sufficiently available.

Keywords: bauxite, alumina, aluminum, energy, electricity, coal, NPP
\end{abstract}

\section{PENDAHULUAN}

Salah satu kekayaan alam yang terdapat di Kalimantan Barat adalah bahan mineral aluminium yang terkandung di dalam bahan bauksit, yang layak tambang pada kisar 45-65\% alumina [1]. Untuk memisahkan aluminia dibutuhkan pabrik peleburan, yang dibangun di atas lahan seluas 288 hektare di tiga desa di
Kabupaten Mempawah, Kalimantan Barat. Proyek smelter grade alumina ini akan memiliki kapasitas awal sebesar 1 juta ton alumina per tahun yang juga akan dilengkapi dengan pembangkit listrik tenaga batubara sebesar 3x25 megawatt [2]. Keberadaan proyek ini tentunya akan memacu roda perekonomian di Provinsi Kalimantan Barat. Dengan adanya 
pengembangan potensi daerah akan terjadi perluasan lapangan kerja baik langsung maupun tidak langsung, serta program pemberdayaan masyarakat sekitar lokasi proyek [2]. Hasil kajian menggambarkan bahwa dalam jangka pendek, keberadaan industri hilirisasi mineral bauksit berdampak pada kenaikan nilai PDB nominal, pendapatan rumah tangga, keuntungan perusahaan dan penerimaan perpajakan tetapi dengan besaran yang belum signifikan [3].

Provinsi Kalimantan Barat mempunyai luas wilayah sekitar $146.807 \mathrm{~km}^{2}$ atau 7,53 persen dari luas Indonesia atau 1,13 kali luas pulau Jawa, yang membentang lurus dari utara ke selatan sepanjang lebih dari $600 \mathrm{~km}$ dan sekitar $850 \mathrm{~km}$ dari Barat ke Timur [4].

Secara keseluruhan Kalimantan merupakan wilayah yang bersifat radial ke segala arah yang memungkinkan interkoneksi listrik tersambung secara radial pula. Ini berarti selain tersambung dengan Kalimantan Tengah juga dapat tersambung dengan Kalimantan Timur. Wilayah Kalimantan Tengah dapat tersambung ke Kalimantan Barat, Kalimantan Selatan dan Kalimantan Timur, sedangkan Kalimantan Timur dapat tersambung ke semua Provinsi yang ada di Kalimantan, yaitu ke Kalimantan Barat, Kalimantan Tengah, Kalimantan Selatan dan Kalimantan Utara. Gambar 1 menunjukkan posisi Provinsi Kalimantan Barat.

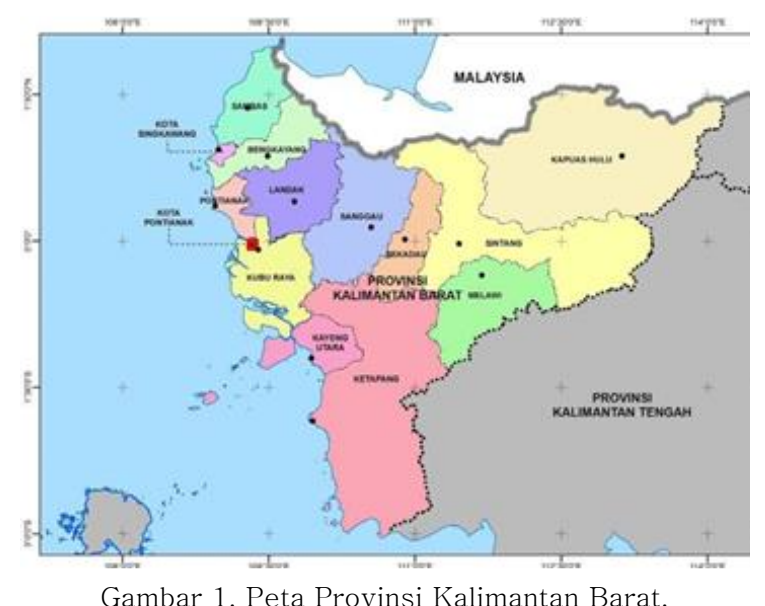

Jumlah penduduk Kalimantan Barat pada tahun 2019 menurut proyeksi BPS adalah 5,07 juta jiwa terdiri dari 2,58 juta laki-laki dan 2,49 juta perempuan [5]. Posisi geografis Kalimantan Barat terletak di bagian barat Pulau Kalimantan atau di antara garis $2^{\circ} 08^{\prime}$ LU dan 3 '05' LS serta di antara $108^{\circ} 0^{\prime}$ BT dan $114^{\circ} 10^{\prime}$ BT.
Kajian tentang kebutuhan energi untuk industri smelter diperlukan terkait dengan upaya penyediaan tenaga listrik yang dibutuhkan dalam dunia industri. Sumber energi panas langsung yang paling potensial untuk digunakan pada industri smelter aluminia adalah batubara, yang dapat menyediakan panas dan listrik untuk berbagai keperluan langsung maupun tidak langsung dalam sistem pengolahan bahan industri. Sedangkan energi dalam bentuk listrik dibutuhkan pada fasilitas pendukung smelter alumina yang juga akan berkembang sesuai dengan intensitas pengembangannya. Pada fase pengembangan industri smelter hingga grade aluminium yang diproyeksikan pada masa selanjutnya akan mendorong kebutuhan energi listriknya yang jauh lebih besar, karena smelter grade aluminium mengkonsumsi energi listrik dalam intensitas tinggi sehingga dibutuhkan kapasitas pembangkit dalam skala besar yang dapat disediakan oleh PLTU batubara dan PLTN.

Dari sisi pengembangan kapasitas pembangkit listrik di Kalimantan Barat tentunya tidak terlepas dari berbagai kendala. Salah satunya kendala adalah bahwa daerah ini tidak mempunyai cukup sumberdaya energi baik energi fosil, tenaga panas bumi maupun tenaga air. Pengembangan pembangkit listrik di wilayah ini membutuhkan sumberdaya energi yang berasal dari daerah sekitarnya. Baik dalam bentuk bahan bakar ataupun dalam bentuk energi listrik melalui jaringan transmisi. Di pihak lain Kalimantan Barat mempunyai sumberdaya uranium sebagai bahan bakar untuk Pembangkit Listrik Tenaga Nuklir (PLTN) yang mampu menghasilkan tenaga listrik dalam skala besar.

Provinsi Kalimantan Utara kaya akan potensi tenaga air namun belum dapat menyerap semua energi listrik dari potensi PLTA ini, sehingga perlu dikaji transfer tenaga listrik ke Provinsi Kalimantan Timur, Kalimantan Selatan, Kalimantan Tengah hingga Kalimantan Barat [6]. Namun pengembangan potensi tenaga air di Kalimantan Utara termasuk jaringan transmisinya tentunya membutuhkan kesiapan yang memadai karena pengiriman jarak jauh akan bermasalah dengan stabilitas jaringan sehingga menyulitkan terealisasi dalam waktu singkat. Dalam hal ini Kalimantan Barat membutuhkan pengembangan kapasitas pembangkit dalam jumlah besar yang 
dapat disediakan dengan PLTU batubara dan PLTN. Di sisi lain kandungan uranium yang tersedia di Provinsi Kalimantan Barat secara bertahap juga perlu dikembangkan sebagai bahan bakar PLTN.

Dilihat dari ketersediaan sumber energi saat ini Kalimantan Barat tidak memiliki sumberdaya energi listrik yang cukup bagi kebutuhan pengembangan industri ke depan, kecuali Kalimantan Barat yang mempunyai sumberdaya uranium yang dapat dimanfaatkan untuk digunakan pada PLTN.

Makalah ini bertujuan untuk menganalisis kebutuhan jenis dan kuantitas energi pada pabrik peleburan bauksit terutama menjadi alumina dan menyinggung aspek pengembangan hingga grade aluminium. Studinya mencakup kajian kuantitatif tentang kebutuhan energi yang digunakan dalam pengolahan bauksit menjadi alumina sebagai bahan baku pembuatan aluminium sehubungan dengan sedang dan akan terus dikembangkan pabrik peleburan (smelter) bauksit menjadi alumina di Wilayah Provinsi Kalimantan Barat.

Hasil yang diharapkan dari analisis ini terutama adalah diperolehnya gambaran kebutuhan energi baik panas maupun listrik untuk smelter bauksit hingga grade aluminium serta fasilitas pendukungnya, serta berbagai aspek terdampak lainnya yang mungkin timbul dari industri ini.

\section{METODOLOGI}

Penelitian dilakukan dengan menggunakan penelusuran pustaka dan analisis benchmarking, dengan melakukan perhitungan pada setiap langkah proses yang melibatkan data dan formula yang berhubungan secara koheren. Besaran yang telah menjadi parameter umum atau berdasarkan pengalaman yang pernah ada di berbagai tempat atau proses, atau yang bersifat tipikal diperlakukan sebagai data empiris. Hal ini meliputi persamaan kimia proses, karakteristik eksergi dan nilai kalor per satuan proses yang merupakan pernyataan misalnya, adalah parameter umum, sedangkan kapasitas, jenis bahan bakar, kadar mineral dan sebagainya adalah variabel khusus. Gambar 2 menunjukkan diagram alir proses perhitungan energi dan

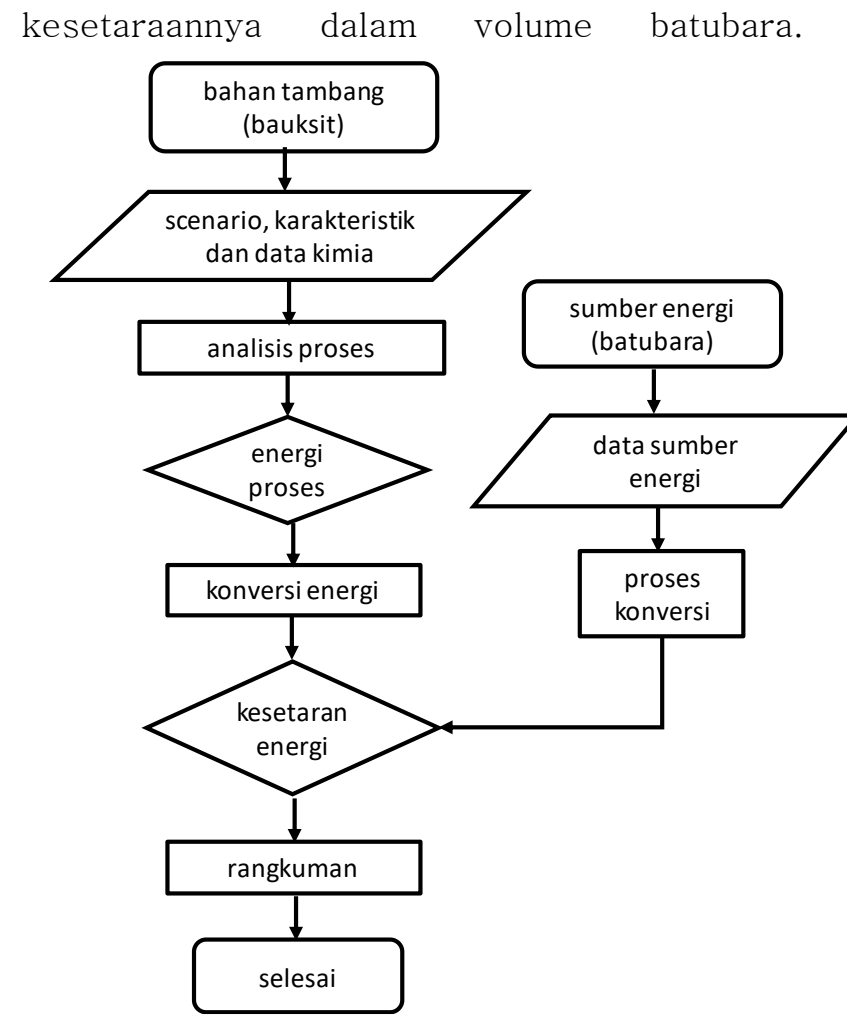

Gambar 2. Diagram alir perhitungan kebutuhan energi.

\section{DATA DAN ASUMSI}

Kabupaten Mempawah, Kalimantan Barat merupakan salah satu wilayah yang akan menjadi pusat industri peleburan (smelter) bahan galian bauksit menjadi alumina sebagai bahan baku pembuatan aluminium. Kabupaten ini berjarak sekitar $75 \mathrm{~km}$ di kawasan pantai sebelah utara dari Kota Pontianak. Pabrik ditargetkan akan menghasilkan satu juta ton alumina dengan kapasitas penyerapan 3 juta ton bauksit per tahun [7][8].

Pembangunan pabrik tersebut adalah sebagai respon dari kewajiban mengolah bahan mentah sebelum diekspor ke luar negeri mulai 12 Januari 2014 lalu dari Peraturan Menteri ESDM Nomor 1 Tahun 2014 [9][2]. Larangan ekspor mineral mentah merupakan amanat UU Nomor 4 Tahun 2009 tentang Pertambangan Mineral dan Batubara. Pemegang Kontrak Karya (KK) dilarang menjual mineral mereka ke luar negeri kecuali jika telah memenuhi sejumlah persyaratan yang ditetapkan dalam Permen ESDM Nomor 5 Tahun 2017 tentang Peningkatan Nilai Tambah Mineral Melalui Kegiatan Pengolahan dan Pemurnian Mineral di Dalam Negeri [10]. 
Berdasarkan data Kementerian ESDM, produksi bauksit nasional saat ini mencapai 40 juta ton per tahun [11]. Dengan diterapkannya UU No.20 Tahun 2009, maka besarnya tenaga listrik yang dibutuhkan untuk produksi alumina di dalam negeri akan membutuhkan ratusan megawatt listrik untuk dibangun. Jika bijih bauksit itu diolah di dalam negeri menjadi alumina, maka nilai tambah yang dihasilkan mencapai kisar hampir 5 kali lipat dibanding jika bauksit tersebut diekspor dalam bentuk bahan mentah [11].

Untuk memproses bauksit menjadi satu ton alumina dibutuhkan energi sebesar 14,5 GJ, termasuk $150 \mathrm{kWh}$ sebagai energi listrik [12]. Sedangkan untuk memproduksi satu ton aluminium dari alumina dibutuhkan energi listrik sebesar 20,1 GJ atau 5,58 MWh untuk proses elektrolisis. Dengan perhitungan kesetaraan massa unsur kimia bahwa alumina adalah $\mathrm{Al}_{2} \mathrm{O}_{3}$, maka untuk mendapatkan 1 ton aluminium dibutuhkan $51 / 27 \times 1$ ton $=1,9$ ton alumina, sehingga energi energi siklus hingga grade alumina adalah 14,5 GJ x 1,9 = 27,4 GJ sebelum mencapai 1 ton grade aluminium. Dengan demikian siklus proses produksi satu ton aluminium dari bauksit membutuhkan energi sebesar $(27,4+20,1)$ GJ $=47,5$ GJ yang terdiri dari bahan bakar batubara dan listrik.

Pabrik alumina Mempawah pada tahap pertama berkapasitas satu juta ton [2], yang mampu menyerap 3 juta ton bauksit per tahun[7]. Untuk memenuhi kebutuhan energi listriknya pabrik difasilitasi dengan PLTU Batubara 3x25 MW [2], selanjutnya kapasitas pabrik akan dikembangkan menjadi 2 juta ton alumina per tahun [13].

\section{Sistem Ketenagalistrikan Kalimantan Barat}

Pengembangan sistem pembangkitan di Kalimantan Barat mengikuti pertumbuhan beban selama ini cenderung menggunakan bahan bakar fosil. Pada awalnya adalah pembangkit berbahan bakar minyak yang berlanjut dengan penggunaan batubara untuk peningkatan kapasitas terpasang dengan biaya produksi listriknya lebih rendah. Sebagai konsekuensinya tingkat emisi meningkat baik secara kuantitatif maupun kualitatif (satuan emisi/kWh). Dari perencanaan PLN (RUPTL 2019-2028), skenario total kapasitas terpasang pembangkit untuk Kalimantan Barat akan meningkat secara signifikan dalam kurun waktu 20 tahun ke depan seperti ditunjukkan pada Gambar 3. Sedangkan penambahan kapasitas akan terdiri dari beberapa jenis pembangkit seperti tertera pada Tabel 1 [14].

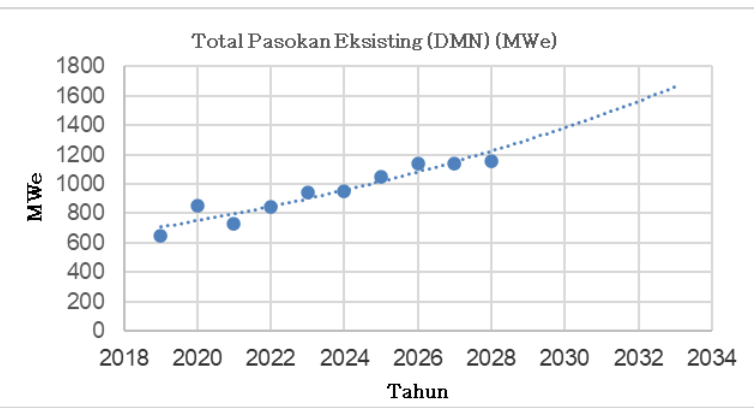

Gambar 3. Total daya mampu netto (MWe) [14].

Pertumbuhan beban puncak Kalimantan Barat amat tergantung pada program industrialisasi di provinsi ini. Kecenderungan program industri ke depan didasarkan pada potensi daerah, yakni bidang pertambangan bauksit, bahan dasar produk logam aluminium, sehingga penyerapan energi di sektor pertambangan ini adalah pada industri smelter. Berdasarkan Undang-undang No. 4 Tahun 2009, Indonesia sudah harus melakukan pemurnian bahan tambang sebelum diekspor, sehingga bahan tersebut mendapatkan nilai tambah, memperluas lapangan kerja dan memperkuat upaya pengembangan teknologi dan industri di dalam negeri.

Tabel 1. Rencana penambahan kapasitas pembangkit hingga 2028 (MWe)[14].

\begin{tabular}{|c|c|c|c|c|c|c|c|c|c|c|c|}
\hline $\begin{array}{c}\text { Jenis } \\
\text { Pembangkit }\end{array}$ & 2019 & 2020 & 2021 & 2022 & 2023 & 2024 & 2025 & 2026 & 2027 & 2028 & Total \\
\hline PLTG & - & - & 100 & - & - & - & - & - & - & - & 100 \\
\hline PLTU & - & - & - & 100 & 100 & & 100 & 100 & - & - & 400 \\
\hline PLTM & - & - & - & - & 2.5 & 10.9 & 7.3 & - & - & - & 20.7 \\
\hline PLTBio & - & 17 & 53 & - & - & - & - & - & - & - & 70 \\
\hline PLTM & - & - & 26 & - & - & - & - & - & - & - & 26 \\
\hline Jumlah & 0 & 17 & 179 & 100 & 102.5 & 10.9 & 107.3 & 100 & 0 & 0 & 616.7 \\
\hline
\end{tabular}


Pembangunan fasilitas smelter perlu disertai dengan peningkatan kapasitas pembangkit listrik. Namun pembangkit yang selama ini sudah dirasa kurang ekonomis seperti yang berbahan bakar diesel perlu digantikan dengan pembangkit yang lebih ekonomis.

Total daya mampu netto (DMN) hingga tahun 2028 akan menjadi 1152 MWe. Gambar 4 menunjukkan bahwa pada tahun 2038 kebutuhan listrik Kalimantan Barat berkisar pada 17200 GWh atau 1963 MWy.

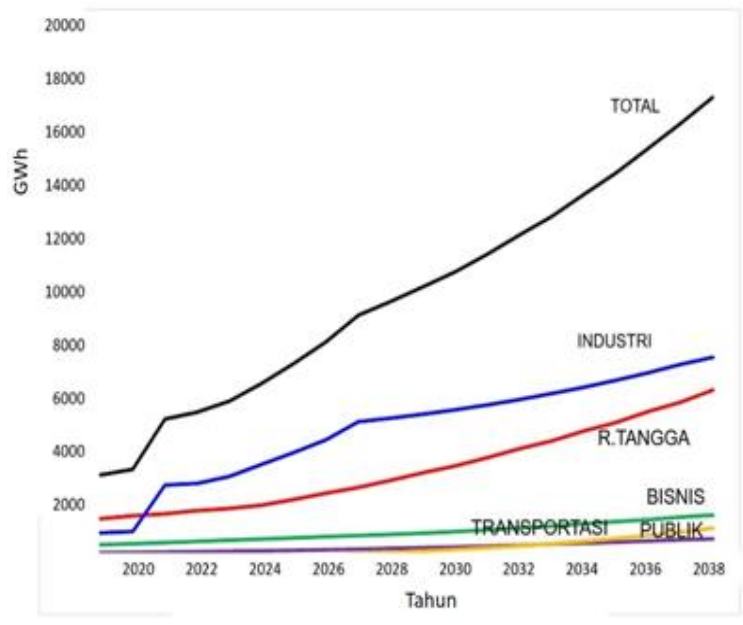

Gambar 4. Proyeksi kebutuhan energi listrik provins kalimantan barat hingga tahun 2028 (GWh) [3].

Angka ini dapat diinterpretasikan bahwa pada tahun tersebut Kalimantan Barat membutuhkan daya mampu netto (DMN) sekitar 1963 MWe atau kapasitas terpasang sebesar 2800 MWe dengan asumsi bahwa faktor kapasitas adalah 0,7. Hal ini bisa terjadi bila skema pengembangan industri smelter di Kalimantan Barat dapat berlangsung sesuai skenario yang direncanakan. Sedangkan jumlah penduduk Kalimantan Barat pada tahun 2038 adalah sekitar 6,1 juta jiwa.

\section{Perbadingan dengan Pulau Jawa}

Data historis penduduk Kalimantan Barat sejak tahun 1970 hingga proyeksi BPS untuk tahun 2019 memberikan kontribusi terhadap angka ekstrapolasi. Dari analisis regresi berdasarkan data tersebut penduduk Kalimantan Barat diproyeksikan akan menjadi sekitar 6,2 juta pada tahun 2040.

Dengan asumsi business as usual (BAU) jumlah penduduk demikian bila mendapatkan energi listrik yang sama seperti penduduk
Pulau Jawa pada tahun 2020 sebesar 1230 kWh/kapita, maka Kalimantan Barat akan membutuhkan kapasitas terpasang sebesar 1587 MWe. Dengan adanya program pengembangan di sektor industri, maka mungkin akan dibutuhkan kapasitas terpasang listrik dalam jumlah yang lebih besar, yang akan tergantung pada intensitas industrialisasi wilayah ini.

\section{PEMBAHASAN}

Salah satu pembangunan smelter di Kalimantan Barat direncanakan mulai berproduksi pada awal 2022. PT Aneka Tambang Tbk (ANTAM) menargetkan pembangunan pabrik pengolahan dan pemurnian grade alumina refinery di Kabupaten Mempawah, Kalimantan Barat dimulai pada Oktober 2019. Pabrik tersebut berkapasitas satu juta ton dengan kemampuan penyerapan 3 juta ton bauksit per tahun. Smelter ini dibangun oleh perusahaan patungan Antam dan Inalum yaitu PT Borneo Alumina Indonesia (BAI) [7].

\section{Energi untuk smelter bauksit}

Dalam pengolahan logam pada umumnya energi dikonsumsi pada semua tahap produksi, mulai dari penambangan, benefisiasi dan ekstraksi kimia baik secara langsung dalam proses maupun melalui produksi input (seperti listrik dan reagen). Jumlah energi langsung dan tidak langsung dari masing-masing tahap di sepanjang rantai proses energi menentukan nilai tambah yang terkandung di dalam logam. Energi yang dikonsumsi dalam pengolahan logam sangat bervariasi, mulai dari sekitar 20 MJ per kilogram untuk timbal dan baja hingga lebih dari 200 MJ per kilogram untuk aluminium. Tahap transformasi kimia (pencucian, peleburan, ekstraksi logam dengan listrik, dan lain lain) adalah yang terbesar berkontribusi dalam mengkonsumsi energi, sedangkan tahap penambangan paling kecil [15].

Di Amerika Serikat pengurangan kebutuhan energi pada industri aluminium adalah sebagai hasil dari kemajuan teknis dan pertumbuhan laju daur ulang. Kedua faktor ini berkontribusi masing-masing 22\% dan 39\% terhadap total pengurangan energi $61 \%$ selama empat puluh tahun terakhir. Dengan berbagai 
ukuran, aluminium tetap menjadi salah satu bahan yang paling intensif energi untuk diproduksi. Hanya pabrik kertas, bensin, baja, dan etilen yang mengkonsumsi lebih banyak energi total di Amerika Serikat dari pada aluminium. Produksi aluminium adalah konsumen energi terbesar dari keluarga logam berdasarkan berat dan merupakan konsumen energi listrik terbesar dari semua produk yang diproduksi [16].

Intensitas energi dari produksi alumina adalah energi yang dikonsumsi di dalam perimeter pabrik oleh proses pemurnian bauksit (termasuk kalsinasi) dan oleh operasi tambahan di lokasi yang terhubung langsung dengan total proses produksi per ton alumina yang dihasilkan [17].

Empat langkah utama dari proses produksi aluminium primer adalah penambangan bauksit, ekstraksi alumina (aluminium oksida), proses Bayer untuk produksi alumina dan proses elektrolisis Hall-Héroult menjadi aluminium ingot.

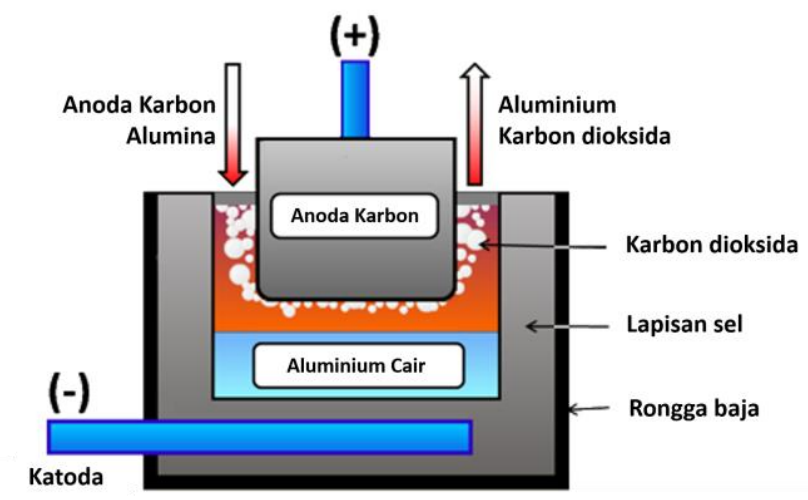

Gambar 5. Skema proses reduksi aluminium melalui proses Hall-Héroult[20].

Semua langkah tersebut membutuhkan sekitar 37 GJ energi termal dan 58 GJ listrik per ton aluminium ingot [18]. Permintaan energi tertinggi adalah dalam proses elektrolisis, dalam bentuk konsumsi listrik seperti ditunjukkan pada Gambar 5.

Persamaan reaksi pada proses reduksi adalah:

$2 \mathrm{Al}_{2} \mathrm{O}_{3}+3 \mathrm{C} \rightarrow 4 \mathrm{Al}+3 \mathrm{CO}_{2}$

Dengan asumsi tidak ada energi yang hilang, maka menurut hukum kekekalan energi berlaku bahwa:

$E_{\text {in }}=\sum_{0}\left(n_{0} \times h_{0}\right)-\sum_{i}\left(n_{i} \times h_{i}\right)$ dengan $E_{\text {in }}$ adalah masukan listrik ke dalam proses, $h_{o}$ adalah entalpi formasi unsur keluar, $h_{i}$ adalah entalpi formasi unsur masuk, $n_{o}$ adalah jumlah mol unsur keluar, dan $n_{i}$ adalah jumlah mol unsur masuk.

Tabel 2 menyajikan nilai-nilai entalpi pembentukan senyawa yang akan digunakan dalam makalah ini [19], dan nilai-nilai ini disubstitusi ke dalam Persamaan (2). Dengan substitusi nilai entalpi pada Tabel 2 ke Persamaan (1) maka satu kilogram aluminium dengan Persamaan (2) diperoleh dengan perhitungan sebagai berikut [20]:

$$
\begin{gathered}
E_{\text {in }}=(1 \times 0)+\frac{3}{4} \times(-393,52)-\frac{1}{2} \times \\
(-1675,69)-\frac{3}{4} \times 0 \\
=542,71 \frac{\mathrm{kJ}}{\mathrm{mol} \mathrm{Al}}=20100 \frac{\mathrm{kJ}}{\mathrm{kg} \mathrm{Al}}=5,58 \frac{\mathrm{kWh}}{\mathrm{kg} \mathrm{Al}}
\end{gathered}
$$

yang merupakan energi terserap pada proses reduksi alumina menjadi aluminium. Kebutuhan energi listrik tersebut hanya untuk penggunaan proses reduksi di dalam pabrik. Untuk konsumsi keseluruhan fasilitas pabrik aluminium beserta lingkungannya menurut data global berkisar antara 10 - $17 \mathrm{MWh}$ per ton aluminium, dengan rerata $14 \mathrm{MWh}$ per ton aluminium [17].

Tabel 2. Nilai entalpi formasi unsur terkait pada suhu ambien [22].

\begin{tabular}{ccc}
\hline Unsur & $\begin{array}{c}\text { Entalpi formasi } \\
(\mathrm{MJ} / \mathrm{kmol}\end{array}$ & $\begin{array}{c}\text { Entalpi formasi } \\
(\mathrm{MJ} / \mathrm{kg}\end{array}$ \\
\hline $\mathrm{Al}_{2} \mathrm{O}_{3}$ & -1675.69 & -16.428 \\
$\mathrm{CO}_{2}$ & -393.52 & -8.944 \\
$\mathrm{CO}$ & -110.53 & -3.948 \\
$\mathrm{O}_{2}$ & 0 & 0 \\
$\mathrm{C}$ & 0 & 0 \\
\hline
\end{tabular}

\section{Energi untuk pengolahan bauksit}

World Aluminium mencatat bahwa konsumsi energi total untuk produksi alumina dunia pada tahun 2019 adalah 1.134.745 TJ, meliputi 85.515 TJ energi listrik yang memproduksi 123.942 .000 ton alumina. Konsumsi energi dalam produksi alumina dari negara ke negara dan dari waktu ke waktu di dunia berbeda dengan rentang 10,74-15,93 GJ/ton, dengan rerata 13,24 GJ/ton [19].

Dengan demikian siklus proses produksi dari bauksit menjadi satu kilogram 
aluminium membutuhkan energi sebesar sekitar 34,6 MJ yang terdiri dari bahan bakar dan listrik. Bahan bakar yang digunakan di dalam tanur biasanya berupa batubara yang panasnya diambil langsung untuk peleburan. Jika di dalam satu pabrik produksi aluminium dari bauksit maka kebutuhan energi dalam proses langsung dapat berupa energi panas dan listrik. Energi listrik pada level beban dasar akan sangat penting dalam proses grade aluminium, sehingga dari segi penyediaannya adalah berupa jenis pembangkit yang beroperasi pada beban dasar (biaya pokok produksi rendah) seperti PLTA aliran langsung (salah satu contoh PLTA Asahan), PLTU batubara dan PLTN (jenis pembangkit yang diandalkan pada level industri).

\section{Produksi alumina}

Dengan asumsi bahwa semua sumber energi adalah batubara Indonesia dengan nilai kalor $5300 \mathrm{kcal} / \mathrm{kg}$, maka untuk mendapatkan satu ton alumina membutuhkan energi sebesar 14,5 GJ, termasuk di dalamnya tenaga listrik sebesar 150 kWh. Nilainya dapat dikonversi menjadi kuantitas bahan bakar batubara sebagai berikut:

Energi Listrik $=150 \mathrm{kWh}$

$$
\begin{gathered}
150 \mathrm{kWh} \times \frac{3600 \mathrm{~J}}{\mathrm{Wh}} \times \frac{1}{0,3}=1,8 \mathrm{GJ} \\
1,8 \mathrm{GJ} \times \frac{0,24 \mathrm{cal}}{\mathrm{J}} \times \frac{\mathrm{kg}}{5300 \mathrm{kcal}}=81,51 \mathrm{~kg}
\end{gathered}
$$

Energi Panas $=14,5$ GJ $-1,8$ GJ $=11,7$ GJ

Dengan asumsi bahwa nilai kalor ratarata batubara Indonesia adalah $5300 \mathrm{kcal} / \mathrm{kg}$, maka untuk mendapatkan energi panas ini dibutuhkan kuantitas batubara sebesar:

$$
11,7 \mathrm{GJ} \times \frac{0,24 \mathrm{cal}}{\mathrm{J}} \times \frac{\mathrm{kg}}{5300 \mathrm{kcal}}=529,81 \mathrm{~kg}
$$

Jadi kebutuhan batubara dengan nilai kalor tersebut di atas menjadi energi listrik dan energi panas untuk produksi satu ton alumina adalah $81,51+529,81=611,32 \mathrm{~kg}$. Nilai ini setara dengan 611,32 ribu ton untuk menghasilkan satu juta ton alumina. Dengan asumsi bahwa kebutuhan energi pabrik dipasok dengan batubara, kisaran kebutuhan energi untuk proses dari bauksit manjadi alumina adalah seperti pada Tabel 3.

Dari Tabel 3 diperoleh bahwa untuk produksi satu juta ton alumina per tahun dibutuhkan energi listrik untuk kebutuhan dasar pabrik sebesar 150 ribu MWh per tahun atau setara 25 MW (pada faktor kapasitas 70\%). Nilai ini akan menjadi sekitar $2-3$ kali $25 \mathrm{MW}$ untuk kebutuhan total yang meliputi untuk pengembangan kapasitas menjadi 2 juta ton/tahun, fasilitas pendukung dan lingkungan sekitarnya.

Di sisi lain penambangan bauksit membutuhkan energi yang relatif rendah, dibandingkan dengan langkah-langkah lainnya dalam proses produksi aluminium, dengan kurang dari 1,5 kilogram bahan bakar minyak diesel dan kurang dari $5 \mathrm{kWh}$ listrik yang dikonsumsi per ton bauksit yang ditambang [12].

\section{Produksi aluminium}

Dalam praktiknya jumlah aluminium yang diprediksi berdasarkan hukum Faraday tidak pernah diperoleh. Dalam reaksi produksi aluminium, sejumlah logam yang dibuat di katoda larut ke dalam elektrolit pada lapisan batas pada antarmuka bak logam dan diangkut ke zona terjadinya reaksi oksidasi yang dikenal dalam industri sebagai reaksi balik oleh gas $\mathrm{CO}$ yang membentuk gas $\mathrm{CO}$ dan $\mathrm{Al}_{2} \mathrm{O}_{3}$ sebagai produk. Konsentrasi CO yang dihasilkan oleh reaksi balik dalam sel-sel ini biasanya sekitar $10 \%$ [21].

Tabel 3. Kebutuhan batubara* sebagai sumber energi pabrik alumina.

\begin{tabular}{ccccc}
\hline $\begin{array}{c}\text { Kapasitas produksi } \\
\text { alumina }\end{array}$ & Energi & Kuantitas & $\begin{array}{c}\text { Setara aktual } \\
\text { batubara (ton) }\end{array}$ & $\begin{array}{c}\text { Total kebutuhan } \\
\text { batubara (ton) }\end{array}$ \\
\hline \multirow{2}{*}{1 juta ton } & Listrik (MWh) & 150.000 & 81.510 & 611.320 \\
& Panas (TJ) & 11.700 & 529.810 & \\
2 juta ton & Listrik (MWh) & 300.000 & 163,020 & $1.222,640$ \\
& Panas (TJ) & 23.400 & $1.059,620$ & \\
\hline
\end{tabular}

*Dengan asumsi bahwa nilai kalor rerata batubara $\sim 5300 \mathrm{kcal} / \mathrm{kg}$. 
Untuk memproduksi satu ton aluminium dari alumina sebagaimana diuraikan di atas adalah 5,58 MWh $(=20,09$ GJ $)$, yang membutuhkan batubara sebesar:

$$
\begin{aligned}
& 5,58 \mathrm{MWh} \times \frac{3600 \mathrm{~J}}{\mathrm{Wh}} \times \frac{0,24 \mathrm{cal}}{\mathrm{J}} \times \\
& \frac{\mathrm{kg}}{5300 \mathrm{kcal}} \times \frac{1}{0,3}=3032,15 \mathrm{~kg}
\end{aligned}
$$

sehingga total kebutuhan batubara dalam siklus dari bauksit menjadi 1 ton aluminium adalah $51 / 27 \times 529,81 \mathrm{~kg}+3032,15 \mathrm{~kg}=4032,9 \mathrm{~kg}$ yang setara dengan 89,06 GJ/ton aluminium. Dari angka ini pada kisaran $14 \mathrm{MWh}$ atau 152,73 GJ (pada kesetaraan aktual) adalah dalam bentuk listrik dengan asumsi bahwa efisiensi produksi listrik pada pembangkit termal adalah $33 \%$.

Kebutuhan energi listrik di dalam pabrik dari grade alumina menjadi aluminium berdasar data global [17], berkisar antara $12-15$ MWh (atau rata-rata $14 \mathrm{MWh}$ ) per ton aluminium, yang tergantung pada faktor efisiensi dan pengelolaan energi pada pabrik. Maka untuk kapasitas produksi satu juta ton aluminium akan membutuhkan pembangkit listrik sebesar:

$$
10^{6} \text { ton } \times \frac{14 \mathrm{MWh}}{\text { ton }} \times \frac{1}{0,8 \mathrm{y}} \times \frac{\mathrm{y}}{8760 \mathrm{~h}} \approx 2000 \mathrm{MW}
$$

Angka tersebut berdasarkan asumsi bahwa faktor kapasitas pembangkit $80 \%$ dan jumlah jam satu tahun adalah 8760. Namun angka ini juga masih terpengaruh oleh faktor kapasitas ril dan efisiensi penggunaan listrik untuk segala kebutuhan di lingkungan pabrik.

Konteks ini mengindikasikan bahwa dibutuhkan jumlah besar energi listrik dalam pengolahan bauksit sampai menjadi aluminium sebagai bahan murni. Kebutuhan energi listrik yang begitu besar tentunya hanya akan terpenuhi dengan pembangkit listrik berskala besar seperti PLTU, PLTA skala besar dan PLTN. Namun ketiadaan sumber tenaga air yang besar, begitupun batubara dan energi fosil lainnya, maka Kalimantan Barat yang memiliki sumber uranium mempunyai pilihan terbaik untuk penggunaan PLTN. Tanpa ketersediaan pembangkit berskala besar pengolahan bauksit di Provinsi Kalimantan Barat akan terhenti hanya sampai grade alumina.

\section{KESIMPULAN}

Hasil analisis diperoleh bahwa kebutuhan energi setara untuk grade alumina adalah pada kisar 611 ribu ton batubara untuk menghasilkan satu juta ton alumina. Pengolahan dari alumina menjadi satu juta ton aluminium per tahun membutuhkan ketersediaan pembangkit listrik sebesar 2 ribu MW. Pembangunan pabrik peleburan (smelter) bauksit menjadi alumina akan menimbulkan kenaikan permintaan energi yang signifikan di Kalimantan Barat. Laju konsumsi energi untuk pengolahan bauksit menjadi alumina terhitung sebagai energi yang masuk ke dalam pabrik untuk proses pemurnian bauksit dan untuk operasi pendukung lainnya di lokasi yang terhubung langsung dengan total proses produksi. Sementara untuk pengolahan alumina menjadi grade aluminium membutuhkan energi listrik yang begitu besar dan hanya dapat terpenuhi dengan menyediakan pembangkit listrik berskala besar. Karena provinsi ini tidak memiliki sumber energi fosil maupun sumber energi lainnya untuk skala industri aluminium, maka penyediaan energi listrik untuk skala industri ini membutuhkan pasokan dari luar provinsi atau mungkin lebih memadai dengan PLTN berskala besar.

\section{DAFTAR ACUAN}

[1] N. Jafar, "Analisis Unsur Endapan Bauksit Menggunakan X-Ray Fluorescence (Xrf) Pt. Antam Tbk. Unit Geomin Daerah Kenco Kabupaten Landak Provinsi Kalimantan Barat," J. Chem. Process Eng., vol. 2, no. 1, p. 46, 2017.

[2] --, "Bangun Pabrik Smelter Alumina, AntamInalum Rogoh Rp 12 T,” CNBC Indonesia, pp. 1-3, 01-Jul-2020.

[3] --, "Dampak Hilirisasi Bauksit Terhadap Perekonomian Regional Provinsi Kalimantan Barat," Pusat Data dan Teknologi Informasi Kementerian Energi Dan Sumber Daya Mineral 2016, 2016, pp. 1-98.

[4] --, Kalimantan Barat Dalam Angka. BPS Kalimantan Barat, 2019.

[5] Badan Pusat Statistik, Statistik Indonesia 2019. Jakarta Pusat, DKI Jakarta 10720: Badan Pusat Statistik, 2010.

[6] Kementerian Energi dan Sumber Daya Mineral, "Rencana Umum Kelistrikan Nasional," vol. (5)2, no. 2, pp. 285-299, 2019.

[7] Ihya Ulum Aldin, "Antam Target Pembangunan Smelter Alumina di Mempawah Dimulai Oktober," Katadata.co.id, pp. 19-20, 20-Sep-2020.

[8] --, “'Smelter' di Mempawah Kalbar hasilkan satu 
juta ton alumina per tahun," ANTARANEWS.COM, 13-Jan-2020.

[9] --, "Kadin minta solusi usaha bauksit," AntaraNews Kalbar, pp. 22-23, 07-Aug-2020.

[10] --, "Menelisik Soal Kewajiban dan Kendala Membangun Smelter," Hukumonline.com, no. March 2017, pp. 1-2, 22-Jun-2020.

[11] Y. Petriella, "Pembangunan Smelter Bauksit Bintan Alumina Indonesia Capai 62 , 5 Persen," Ekonomi.bisnis.com, pp. 2020-2022, 30-Jan-2020.

[12] --, 'Aluminium is an 'energy bank'; most of the original input can be recovered every time the product is recycled." ALU, Aluminium for Future Generations, pp. 1-3, 2016.

[13] F. Yunianto, "Smelter Inalum-Antam gradibangun, Indonesia stop impor alumina 2022," AntaraNews.com, no. April, pp. 2019-2020, 2019.

[14] PT. Perusahaan Listrik Negara, "Rencana Usaha Penyediaan Tenaga Listrik 2019-2028," PT. Perusah. List. Negara, pp. 2019-2028, 2019.

[15] J. Rankin, "Energy Use in Metal Production," High Temp. Process. Symp., no. Table 1, p. 9, 2012.

[16] --, U.S. Energy Requirements for Aluminum Production: Historical Perspective, Theoretical Limits and Current Practices. U.S. Department of
Energy, 2007.

[17] W. Aluminium, M. Alumina, and R. Energy, "Metallurgical alumina refining energy intensity," pp. 1-3, 2020.

[18] J. A. Moya et al., Energy Efficiency and GHG Emissions: Prospective Scenarios for the Aluminium Industry. 2015.

[19] World Aluminium, "Metallurgical Alumina Refining Fuel Consumption," 2020. [Online]. Available: http://www.world-

aluminium.org/statistics/metallurgical-aluminarefining-fuel-consumption/.

[20] M. Obaidat, A. Al-Ghandoor, P. Phelan, R. Villalobos, and A. Alkhalidi, "Energy and exergy analyses of different aluminum reduction technologies," Sustain., vol. 10, no. 4, pp. 1-21, 2018.

[21] A. T. Tabereaux and R. D. Peterson, "Aluminum Production,” Treatise Process Metall., vol. 3, pp. 839-917, 2014.

[22] --, "Enthaphy of Formation Table," vol. 5, --, 2006, pp. 389-416. 